\title{
Percepções e representações socioambientais de estudantes brasileiros e portugueses sobre o Meio Ambiente evidenciadas em desenhos
}

\section{Social and environmental perceptions and representations of brazilian and portuguese students about the Environment as evidenced in drawings}

\section{Percepciones sociales y ambientales y representaciones de estudiantes brasileños y portugueses sobre el Medio Ambiente como se evidencia en los dibujos}

\author{
Gilivã Antonio Fridrich ${ }^{1}$ \\ Dr. Luiz Carlos Serramo Lopez ${ }^{2}$ \\ Dra. Maria de Fátima Camarotti ${ }^{3}$ \\ Dr. António José Guerner Dias ${ }^{4}$ \\ Thiago Siqueira Paiva de Souza ${ }^{5}$ \\ Luane Maria Melo Azeredo ${ }^{6}$
}

\begin{abstract}
Resumo
A interação humana com o meio ambiente pode ser compreendida como uma condição inicial de nossa espécie numa relação biofílica com influências nos contextos familiares, comunitários e escolares. Esta investigação analisou as percepções e representações socioambientais de estudantes brasileiros e portugueses, em relação ao meio ambiente e os elementos que o constituem, através de desenhos. Utilizou-se a metodologia quantiqualitativa com o uso da análise de conteúdo e discricional, aplicada em 343 estudantes, matriculados num total de treze escolas municipais públicas de cidades brasileiras e portuguesas. Com a análise sistemática dos desenhos constatou-se que os estudantes representam a problemática ambiental, referenciando o ser humano como protagonista. Entre os problemas atuais antrópicos, ressaltam-se os resíduos sólidos como um dos grandes fatores de impacto socioambiental. Verifica-se, nos estudantes, grandes preocupações pró-ambientais. Independente das regiões e países, os estudantes transcendem a necessidade de mudanças comportamentais e de paradigmas nos humanos com o meio ambiente.
\end{abstract}

Palavras-chave: Expressões gráficas. Natureza. Problemas Ambientais. Pró-ambientais.

\begin{abstract}
He human interaction with the environment could be understood as an initial condition of our species in a biophilic relationship with influences on our family, community and school contexts. This research analysed the socio-environmental perceptions and representations of Brazilian and Portuguese students, in relation to

\footnotetext{
${ }^{1}$ Doutorando em Desenvolvimento e Meio Ambiente - Universidade Federal da Paraíba, UFPB. Universidade Federal da Paraíba, Centro de Ciências Exatas e da Natureza - Campus I. profgilivan@gmail.com

${ }^{2}$ Doutorado em Ecologia - Universidade Federal do Rio de Janeiro, UFRJ. Professor Adjunto - Universidade Federal da Paraíba, UFPB. Universidade Federal da Paraíba, Centro de Ciências Exatas e da Natureza - Campus I, Departamento de Sistemática e Ecologia. lcslopez@gmail.com

${ }^{3}$ Doutorado em Ciências Biológicas. Professora Associada II, Universidade Federal da Paraíba, Centro de Educação - Campus I. Departamento de Metodologia da Educação. fcamarotti@yahoo.com.br

${ }^{4}$ Doutorado em Geologia - Universidade do Porto da Faculdade de Ciências - Portugal. Professor Auxiliar. Departamento de Geociências, Ambiente e Ordenamento do Território- Universidade do Porto da Faculdade de Ciências - Portugal. agdias@fc.up.pt

${ }^{5}$ Doutorando em Desenvolvimento e Meio Ambiente - Universidade Federal da Paraíba. Professor Assistente Universidade Federal da Paraíba, UFPB. Universidade Federal da Paraíba, Centro de Ciências Agrárias Campus III, Departamento de Ciências Fundamentais e Sociais. DCFS - UFPB - Campus II Cidade Universitária 58397000 - Areia, PB - Brasil. sps.thiago@gmail.com

${ }^{6}$ Doutorado em andamento em Etnobiologia e Conservação da Natureza - Universidade Federal Rural de Pernambuco, UFRP. Universidade Federal da Paraíba, Centro de Ciências Exatas e da Natureza - Campus I. Rua Maria Silvestre dos Santos, Jardim Cidade Universitária, 58051837 - João Pessoa, PB - Brasil. luaneazeredo@gmail.com
} 
environment and the elements that constituted, through drawings. Quanti-qualitative methodology was used utilizing the content and discretionary analysis applied to 343 students, enrolled in thirteen public municipal schools in Brazilian and Portuguese cities. The systematic analysis of the drawings found that the students represents the environmental problematic referencing the human beings as protagonist. One of the current anthropic problems, we emphasize the solid waste as one of the major factors of social and environmental impact. We verify in the students a big pro-environmental concern. Regardless of regions and countries, the students transcend the need for behavioural changes and the paradigms in humans with the environment.

Keywords: Graphic expressions. Nature. Environmental problems. Pro-environmental

\section{Resumen}

La interacción humana con el medio ambiente puede entenderse como una condición inicial de nuestra especie en una relación biofílica con influencias en contextos familiares, comunitarios y escolares. Esta investigación analizó las percepciones y representaciones sociales y ambientales de los estudiantes brasileños y portugueses, en relación con el medio ambiente y los elementos que lo constituyen, a través de dibujos. Se utilizó metodología cuantitativa y cualitativa con uso de análisis de contenido, categórico y discrecional. Participaron 343 estudiantes, matriculados en un total de trece escuelas públicas municipales en ciudades brasileñas y portuguesas. Con el análisis sistemático de los dibujos se descubrió que los estudiantes representan el problema ambiental haciendo referencia al ser humano como protagonista. Uno de los problemas antrópicos actuales son los residuos sólidos como uno de los principales factores de impacto socioambiental. Los estudiantes tienen grandes preocupaciones proambientales. Independientemente de las regiones y países, los estudiantes trascienden la necesidad de cambios de comportamiento y paradigmas en humanos con el medio ambiente.

Palabras clave: Expresiones gráficas. La naturaleza. Problemas ambientales. Proambiental.

\section{Introdução}

A interação humana com o ambiente pode ser compreendida como uma condição inicial de nossa espécie, pois existe uma tendência de preocupar-se com a natureza e os elementos que a constituem numa relação biofílica (KAHN, 1997; WILSON, 1984). Essa conexão com o natural pode ser definida através de conceitos, crenças, pertencimento, envolvimento afetivo, sensibilização, consciência (SCHULTZ, 2009), representação (JODELET, 2011) e percepções ambientais (TUAN, 1990).

É inegável de que tudo está interligado por meio de relações ecológicas em um planeta com recursos finitos, e percebe-se que as ações humanas constroem, transformam e modificam as sociedades no decorrer dos tempos. Essa relação com o meio não respeita os ciclos biológicos da natureza, uma vez que vem dizimando rapidamente seus recursos (FRIDRICH; BALDIN, 2017).

É visível que questões ambientais, sejam essas, a perda de biodiversidade, as mudanças climáticas, poluição do solo, recursos hídricos, entre outras, são causadas principalmente pelos humanos (STEFFEN et al., 2015) e decorrentes de um pensamento e comportamento antropocêntrico (REIGOTA, 2012), trazendo consequências negativas para os seres vivos (SCHULTZ; KAISER, 2012) e, levando, em um curto espaço de tempo, ao "caos" ambiental (FRIDRICH; BALDIN, 2017).

Esses são alguns dos fatos emergentes à grande problemática socioambiental, evidenciada pela estreita conexão entre os modos sociais humanos, com a degradação dos ecossistemas do planeta. Isso ocorre devido à falta de sensibilização, de preocupações ambientais e de ações sustentáveis efetivas. Logo, são necessárias mudanças de paradigmas e comportamentos nos humanos, o que deve ocorrer nos espaços informais e formais, pela educação em todos os níveis de ensino escolar buscando ressignificar a existência humana terrestre (MORIN, 2000). Como alternativa para a reversão desse quadro, busca-se a construção de uma sociedade sustentável, através de um modelo de desenvolvimento que 
alinhe os valores sociais, econômicos e ambientais.

Essas relações ambientais são fortalecidas com a Educação Ambiental (EA), a qual se constitui em um processo contínuo e formativo do indivíduo ambientalmente ético e crítico, na reorientação e capacitação das pessoas para a construção de um novo estilo, na mudança de paradigmas, na formação de cidadãos sensibilizados, para ações que permeiem na melhoria sustentável do seu ambiente, comprometendo-se com a vida e o bem-estar de todos (REIGOTA, 2012).

Nesse encaminhamento, retratam-se, neste artigo, as visões, sentimentos, simbolismo e valores que os educandos possuem em relação ao meio ambiente, buscando conhecer suas percepções referentes à importância da preservação e conservação do mesmo, sob a ótica da realidade local, regional e global. O objetivo do estudo que subsidia este texto, centrou-se em: análises das percepções e representações socioambientais de estudantes brasileiros e portugueses, em relação ao meio ambiente e os elementos que o constituem, através de expressões gráficas em desenhos.

\section{Metodologia}

Este estudo seguiu uma abordagem qualitativa e quantitativa com análise de conteúdo, categórica e discricional, a qual procurou abranger os aspectos variados em um contexto de percepções e representações socioambientais, por meio de expressões gráficas (desenhos).

Esta investigação, de abrangência internacional, realizada nos países Brasil e Portugal, incluiu um total de 343 estudantes do $5^{\circ}$ ano do Ensino Fundamental Anos Iniciais, para as escolas brasileiras e do $5^{\circ}$ ano do $2^{\circ}$ Ciclo de ensino para escolas portuguesas. Desse total, distribuíram-se: $n=102$ João Pessoa (JP), n=96 União da Vitória (UV), n=34 Porto União (PU), essas, regiões brasileiras. Em Portugal (PT), n=75 Porto e $n=36$ em Gondomar (PT). As coletas de dados ${ }^{7}$ foram realizadas nos períodos de setembro e outubro 2017 (escolas de JP), março e abril de 2018 (escolas de UV e PU), dezembro de 2018 e janeiro de 2019 (escolas de PT).

Desse quantitativos, na cidade de João Pessoa (PB), participaram 54 estudantes do sexo masculino (53\%) e 48 do sexo feminino (47\%), com faixa etária entre dez a dezessete anos. Nas cidades de União da Vitória (PR), cinquenta do sexo masculino (52\%) e 46 do sexo feminino (48\%) com idades entre nove e treze anos. Em Porto União (SC), foram quinze participantes do sexo masculino $(44 \%)$ e dezenove do sexo feminino $(56 \%)$, com faixa etária entre nove a onze anos. Já, em Portugal na cidade do Porto foram 32 do sexo masculino $(43 \%)$ e 43 do sexo feminino (57\%). Na cidade de Gondomar, foram quinze alunos masculinos (42\%) e $21(58 \%)$ do sexo feminino, a idade dos estudantes de ambas cidades foi de nove a doze anos.

Estão inseridas neste estudo dez escolas públicas, municipais, brasileiras, destas, quatro localizadas em João Pessoa, região Nordeste do Brasil (duas escolas inseridas na área urbana e duas na área periférica). Outras quatro escolas em União da Vitória, sendo duas situadas na área urbana e duas na área periférica. No município de Porto União foram duas escolas periféricas. Estes últimos municípios estão inseridos na região Sul do Brasil. E por fim, duas escolas públicas urbanas inseridas na cidade do Porto e uma periférica da cidade de Gondomar, ambas de Portugal (Norte de Portugal), totalizando, assim, treze escolas incluídas neste estudo.

\footnotetext{
${ }^{7}$ A pesquisa que deu origem a este artigo foi aprovada pelo do Comitê de Ética e Pesquisa do Centro de Saúde da Universidade Federal da Paraíba, sob o nº. 2.506.482 em consonância com a Resolução nº 196 de 10/10/1996 do Conselho Nacional de Saúde (CNS).
} 
Para justificar a escolha do público estudado, levou-se em consideração a faixa etária para esses níveis de ensino, que corresponde de nove a dez anos. Destacam-se como características, nessa idade, o fato de os estudantes estarem em processo de construção social, do caráter e identidade, conscientização e respeito ao meio em que estão inseridos (meio ambiente).

$\mathrm{O}$ ambiente educacional constitui-se num local com possibilidade de analisar as percepções individuais e as representações sociais por meio de suas vivências educativas. Para isso, foram selecionadas as três regiões distintas geograficamente. As duas regiões brasileiras (Nordeste e Sul) por se constituírem de aspectos florísticos semelhantes, porém com a cultura da população diferenciada em questões alimentares, moradias, diversões e outros. E como diferenças, as escolas da região Nordeste estão inseridas no litoral brasileiro, o que difere da região Sul, com suas escolas distante geograficamente do ambiente litorâneo, com isso observa-se o clima e a topofilia diferenciada.

Assim como na região Nordeste do Brasil, as escolas inseridas na região Norte de Portugal são litorâneas, com isso, poder-se-ia verificar as diferenças nas percepções dos estudantes quanto a essas duas regiões, pelo fato da biodiversidade ser diferente nesses locais. Em questões culturais, Portugal difere tanto nos costumes, alimentação e hábitos das outras duas regiões brasileiras. Deve-se levar em conta a questão de ensino, o que pode ter grande influência nas concepções dos estudantes quanto ao meio ambiente. Nas regiões brasileiras, seguem conteúdos e formato de ensino semelhantes, se comparado às escolas portuguesas, com métodos de ensino e organização estrutural de conteúdos díspares. Decorrente dessas características, optou-se em desenvolver o estudo nesses locais.

\subsection{A elaboração dos desenhos}

Considera-se que, os estudantes desses níveis de ensino possuem um grandioso universo imaginativo, e que suas atitudes e criatividade são movidas pela imaginação. Nesse sentido, criou-se uma atmosfera imaginativa e instigante para o desenvolvimento e aplicação do instrumento do estudo (TELLES; SILVA, 2012).

Os estudantes foram convidados a expressarem-se através de um desenho, feito em uma folha de papel, com o objetivo de responder ao seguinte questionamento: o que é o meio ambiente para si? Para a confecção dos desenhos foram disponibilizados de 45 a 60 minutos.

Essa dinâmica foi desenvolvida com o fulcro de despertar a imaginação dos estudantes, e foi adaptada de Telles e Silva (2012), a qual é nomeada: Tela de Pintura. A dinâmica foi adotada por caracterizar-se como uma atividade instigadora e imaginativa, pois através do desenho livre, cada estudante foi convidado a imaginar-se como pintor e desenhista e representar sobre o que é o meio ambiente para si.

Para a análise de conteúdo buscou-se Bardin (2009), que faz referência, como um tipo de análise empregada na prática em verificar e investigar mensagens pouco exploradas. Esse é um método empírico e, dependendo do conceito da área trabalhada, dedica-se a uma maneira de interpretação que se pretende como objetivo do estudo. Para a escolha das categorias de análise desta pesquisa, foi considerado o número de vezes que as unidades de registro (elementos) foram expressas nos desenhos.

Assim, foram utilizadas três categorias de análises centrais, organizadas em respectivas unidades de registros. Para a Categoria A: Elementos Naturais: Rio, Mar, Montanha, Plantas, Animais. Na Categoria B: Elementos Humanos e Construídos: Construções, Transporte, Regional, Planeta, Pessoas. Por fim, a Categoria C: Elementos de Sentimentos Ambientais: Problemas ambientais, Pró-ambientais. Ressalta-se que as categorias centrais deste estudo foram adaptadas do estudo de Telles e Silva (2012).

Para as análises quantitativas foi utilizado o programa estatístico R x $643.4 .0 \mathrm{com}$ 
aplicação do Qui quadrado, verificada a significância <0.05, com intervalo de confiança a 95\% das unidades de registros (elementos). Informa-se, ainda, que a pesquisa apresentou uma análise comparativa entre os dados obtidos das escolas brasileiras e portuguesas, verificando a presença e/ou ausência dos elementos quanto a níveis de significância estatística.

\section{Resultados e Discussão}

\subsection{Categoria A - Elementos Naturais}

Nesta categoria foram verificados macroelementos bióticos e abióticos, os quais podem ser constatados nos desenhos elaborados pelos estudantes, evidenciando os elementos naturais (Figura 01).

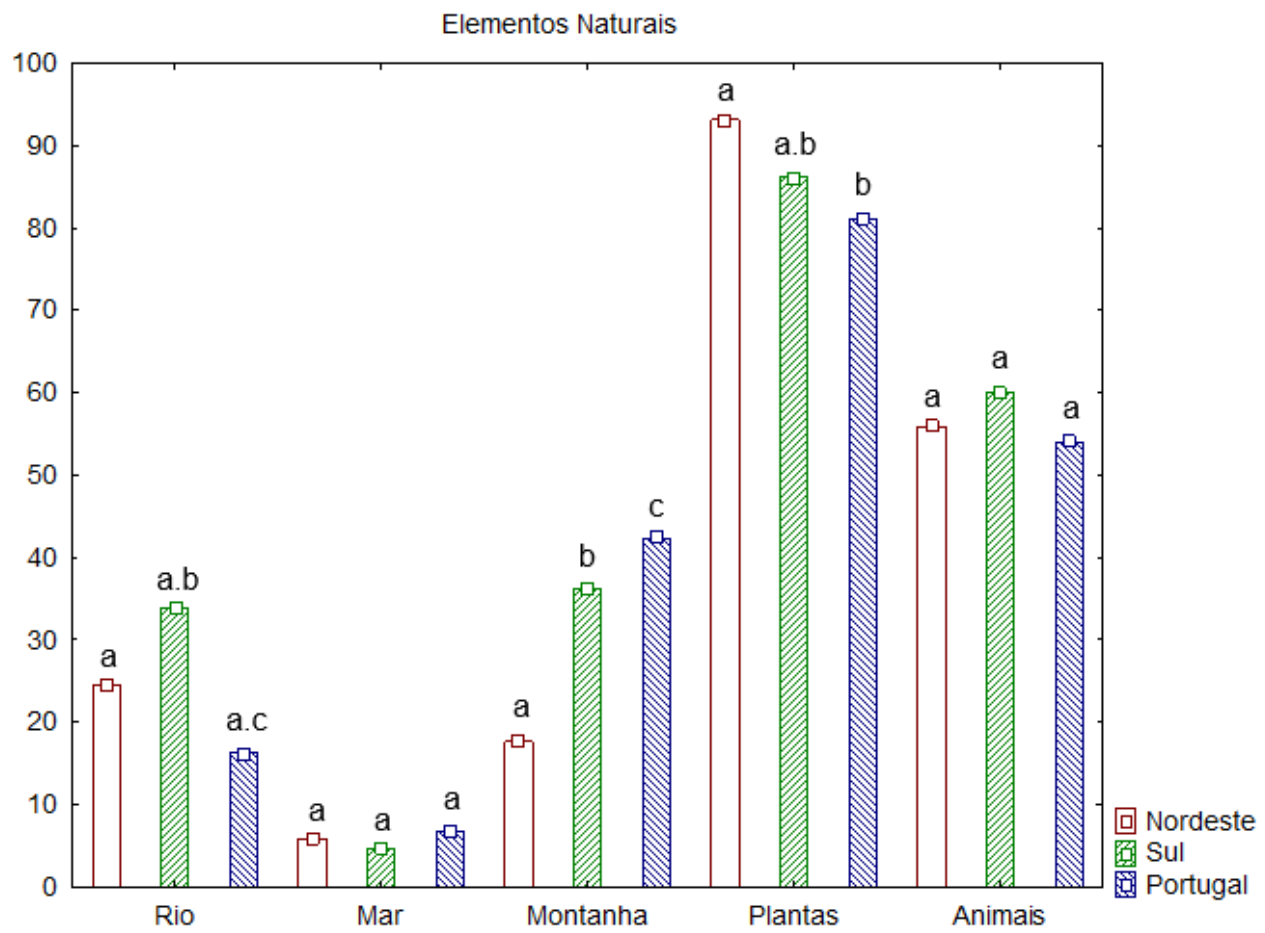

Figura 01 - A categoria central: Elementos Naturais e as unidades de registros destacando-as os valores de significâncias $(<0.05)$ para cada região estudada, Brasil (Nordeste e Sul) e Portugal ${ }^{8}$

Fonte: os autores (2019)

Após os procedimentos metodológicos e uma análise criteriosa dos desenhos, foram selecionados alguns destes (Figura 02) para a exposição das representações dos estudantes quantos aos elementos naturais.

\footnotetext{
${ }^{8}$ Legenda: as letras iguais correspondem a valores não significativos estatisticamente. Para as letras diferentes esses valores foram significativos nas regiões estudadas $(\mathrm{p}<0,05)$.
} 


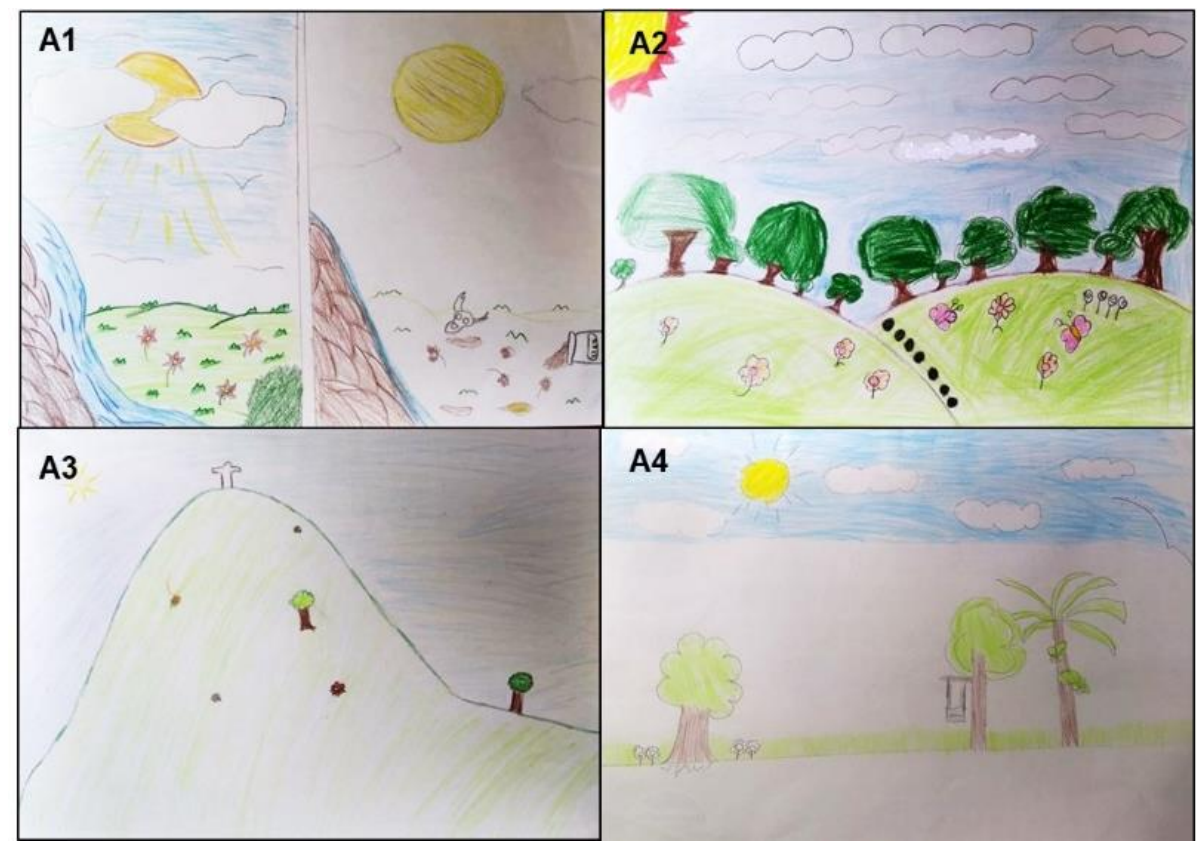

Figura 02 - Representação dos elementos gráficos dos estudantes das escolas de União da Vitória organizados em desenhos A1, A2 e A3) e estudantes das escolas de João Pessoa caracterizado pelo desenho A4 Fonte: os autores (2019)

Para a unidade de registro Rio não se obteve diferenças estatísticas entre as cidades estudadas, porém, há uma representatividade maior dos participantes nos municípios de UV e PU, pelo quantitativo nos desenhos relacionados com os recursos hídricos regionais, dentre esses: rios, córregos, cachoeiras e lagos. Um fator a ser considerado, o qual remete esses estudantes a desenharem elementos relacionados com a água, refere-se ao Rio Iguaçu. Este, pela sua amplitude e extensão geográfica, além de seus benefícios para a população regional para a subsistência, beleza, valores afetivos, históricos, simbolismo e lazer, corta geograficamente essas duas cidades (FRIDRICH; BALDIN, 2017).

Para os estudantes da cidade do Porto (PT), verificou-se esse apreço e simbolismo em relação ao Rio Douro, mostrando sua importância regional e necessidade de cuidado com suas águas.

Os estudantes, nas cidades e regiões, possuem representatividade semelhante quanto ao elemento Rio, pois retrataram em seus desenhos suas belezas, contornos, tamanhos, cores e interações entre recursos faunísticos e florísticos. Além de enaltecer, é possível visualizar nos traços gráficos um grande apelo e preocupações no que tange às águas. Os estudantes mostram grande preocupação no que se reporta aos resíduos sólidos e líquidos, dispensados pelos humanos nos corpos hídricos.

Esse fato refere-se à preocupação ambiental, a qual é projetada em relação às águas e ao meio ambiente, nitidamente vistos na forma em que os estudantes organizaram seus desenhos. Alguns desses estruturaram sua folha em duas partes, e classificaram o meio ambiente em duas categorias: Bom e Ruim. Um maior destaque dessa organização foi realizado pelos estudantes PT, UV e PU. No lado representado como Bom, o desenho mostrava árvores, flores coloridas, aves, montanhas e grandes cachoeiras, paisagens exuberantes, retratando as águas dos rios como um referencial de beleza. Para o lado tido como Ruim, há projeções de locais semelhantes ao anterior, porém, com lixo jogado nos rios e na vegetação, esgotamento urbano dispensado nas águas e a morte de animais, decorrentes dessas situações. Esses fatos podem ser visualizados (Figura 02 A1), com o esboço da preocupação sobre essa problemática ambiental. 
Nessa mesma categoria central emergiu a unidade de registro Mar. De acordo com as análises estatísticas não há diferenças significativas entre os locais estudados. No entanto, verifica-se representatividade maior nos desenhos dos estudantes de UV e PU, retratando a beleza desse recurso natural. Já para os estudantes de PT, nas duas cidades, apresentam os problemas ambientais antrópicos ocasionados nesse recurso hídrico com a dispensação de resíduos sólidos de maneira descontrolada, ocasionando a mortalidade de animais e problemas na saúde pública humana.

Essa unidade de registro, por se tratar de recursos hídricos apresentou características semelhantes à unidade Rio. Um fato a ser considerado em relação às cidades de JP e PT, é devido à sua localização litorânea, sendo essa situação, esperava-se maior representação e reconhecimento local por parte dos estudantes. Pode-se destacar a necessidade de ações de Educação Ambiental efetivas e continuadas para sensibilizar os estudantes quanto à importância desse recurso para a vida na Terra.

Essa unidade de registro (Mar) ficou bastante evidente nos estudantes de UV e PU. Provavelmente, pelo fato de tais cidades estarem geograficamente distantes do mar, e os estudantes projetam a paisagem litorânea com belezas naturais, tranquilidade e afetividade. Um fator para demonstrar esse apego e representatividade quanto ao Mar, pode estar ligado ao período de férias escolares, visto que dirigem-se para regiões litorâneas, demonstrando assim, essa projeção afetiva quanto ao mar.

Alguns estudantes destacaram a grande problemática ambiental atualmente nos mares, fato esse, evidenciado nos desenhos de PT. Para muitos destes, os problemas das praias, mares e oceanos são os contaminantes, depositados ou despejados nos corpos hídricos, tornando-os locais impróprios para a saúde humana. Nessa concepção de poluição, contaminação e degradação, estão em evidência os resíduos sólidos. A problemática maior vincula-se à perda de habitat natural e morte dos animais marinhos pela situação da poluição em específico, isto é, os lixos depositados pelos seres humanos.

Outra unidade de registro que emergiu foi Montanha. Destaca-se a sua diferença a nível estatístico entre todas as regiões estudadas, no entanto, verifica-se maior significância para as cidades UV, PU e PT.

Para os estudantes, esses locais apresentam relevos semelhantes. Os traços de montanhas demonstraram a organização do espaço geográfico acentuado e com rica composição florística, com árvores e flores (Figura 02 A2). Essas evidências destacadas pelos estudantes, em especial de UV e PU, deve-se ao fato de estarem inseridos em uma região de vales, com relevo bastante acentuado, e como destaque em UV o Morro do Cristo, com uma imponente estátua, bastante visitada por turistas para sua contemplação, além da vista panorâmica das cidades circunvizinhas (Figura 02 A3), bastante representativa para o turismo local e regional.

Nessa mesma categoria central, emergiu a unidade de registro Plantas, que apresentou diferença significativa entre Nordeste e Portugal, notam-se valores diferenciados e representativos entre os locais de JP e PT. Para isso, os estudantes, retrataram inúmeros tipos de plantas com tamanhos e formatos diferenciados, com destaque, também, para flores e gramíneas. O quesito regionalismo ficou evidente na cidade de JP, com a representação de várias árvores com frutos (manga, caju, goiaba, entre outros), diversos coqueiros e cactos, representando a flora regional. Já os estudantes de UV e PU esboçaram em alguns desenhos a Araucária angustifólia, tida como árvore símbolo do Estado do Paraná, que também expressa a flora regional. Os estudantes de Portugal trazem mais desenhos quanto às plantas, semelhantes às outras regiões, no entanto destacaram-se tipos de pinheiros como característica do regionalismo.

Outro fato observado nos desenhos é o imaginário, simbolismo e a inocência dos estudantes, ao desenharem faces (olhos, boca, nariz) nas árvores, pode-se levar em 
consideração o pertencimento e conectividade com os elementos naturais. Os desenhos mostravam, ainda, diversas flores coloridas, representando o belo aos olhares deles, característica bastante evidente nos desenhos dos participantes das escolas portuguesas. Esse fato registrado nos desenhos de estudantes portugueses pode guardar relação com a Primavera bem definida, como ocorre em Portugal, e diferente do Inverno, nessa época tem muitas flores silvestres que nascem nos campos, o que não se verifica por exemplo em JP, que os campos ou terrenos baldios não apresentam tantas flores silvestres.

Nessa perspectiva, Martinho e Talamoni (2007) aludem que a predominância de flores em detrimento de outras partes de uma planta parece óbvio devido ao apelo estético e aroma que estas exalam no ambiente. Nessa linha de pensamento, Profice (2016) reforça que os ambientes naturais fornecem um contexto e conteúdo para a exploração, bem como o imaginário infantil e essas vivências de fantasia contribuem para o desenvolvimento biopsicossocial da criança e do jovem.

É nítida a visão do meio ambiente como um local de interação, seja com a fauna e flora ou lazer e diversão. Esse elemento ganha significância nas memórias afetivas dos estudantes, como pode ser observado no registro do balanço que aparece na Figura 02 A4. Nesse sentido, o balanço remete à brincadeira, a qual reforça a essência de criança e a importância da conexão com os ambientes naturais para a sua construção de ser humano (LOUV, 2016).

Ainda, em uma concepção de desenvolvimento humano-biopsicossocial o jovem ao interagir com ambientes, pessoas, seres vivos e objetos, desencadeia e utiliza seus atributos biológicos, psicológicos e sociais. Essas dimensões estão sempre presentes em sua existência, são atualizadas continuadamente pelas vivências e interações dos indivíduos por meio de seus contextos sociais e históricos (PROFICE, 2016). Quando atingirem a idade adulta, essas vivências em áreas naturais e ao ar livre serão mais significativas, podendo ser reproduzidas aos seus descendentes. No entanto, crianças e jovens que não convivem em contato com a natureza podem suprimir essa relação futura, diminuindo sua biofilia, cuidados, proteções e sensibilização ambiental. Nesse sentido, percebe-se a importância da EA continuada na vida humana em especial, na idade infantil.

A última unidade de registro para essa categoria é Animais. Sobre esta, alude-se que em relação à estatística, não há diferenças para nenhuma das cidades estudadas, no entanto, é bastante evidente nos desenhos de todas as cidades e regiões imagens de animais junto aos humanos e elementos naturais.

Em aspectos gráficos gerais, os estudantes enfatizaram muitas borboletas e pássaros, voando livremente numa relação interativa com outros elementos, verificando-se a liberdade e harmonização. Dentre essa fauna identificada, corrobora-se com os estudos de Martinho e Talamoni (2007), Bezerra e Gonçalves (2007) que também identificaram um predomínio dos dois organismos alados: borboletas e aves, reforçando, assim, que esses animais, independentes das regiões e/ou países são referenciados com afetividade e simbolismo por crianças e jovens.

Outros animais foram representados, como os cachorros, cobras, macacos, girafa, leões, cavalos, tartarugas, bicho preguiça, jacaré, peixes, porco-espinho e vacas. Alguns desses são exóticos e/ou não são encontrados nessas cidades. Assim, pode ser considerada a memória afetiva relacionada com esses animais, que em algum momento da vida dos estudantes foi vivenciada.

Nessas concepções, para Pedrini, Costa e Ghilardi (2010), animais que voam e cantam são mais fáceis de serem avistados e percebidos, pelo seu valor estético e sonoro. Já no caso de animais exóticos, como a girafa e os leões, pode-se supor a influência da mídia (filmes, desenhos animados, documentários, séries e programas televisivos ou, ainda, em visitas e aulas de campo em zoológicos, seja por excursões escolares ou passeios familiares) na 
apresentação desses animais para as crianças. Ainda, Schwarz, Sevegnani e André (2007) em seus estudos também encontraram animais alóctones à fauna da região em que se realizou a pesquisa, e isso mostra a forte influência de recursos audiovisuais como os filmes e desenhos veiculados pela mídia em geral.

Observa-se que os estudantes de UV e PU enfatizaram as relações ecológicas estabelecidas entre os animais, aves, macaco, cachorros, caracol, peixes e gatos, além de suas relações com esses. Os fatos abordados, e preocupantes conforme perspectiva dos estudantes, são as relações desarmônicas, estabelecidas entre os seres humanos e os animais. Destacam a mortalidade dos animais ocasionada pela caça, queimadas e poluição decorrentes de ações antrópicas.

Na percepção de um aluno autista de UV, o meio ambiente é representado como um lugar cheio de animais e suas relações ecológicas. Em sua obra, o estudante representou com diversos animais, muitos desses encontrados em zoológicos, esquematizados com legendas significando que, para ele, o meio ambiente é organizado nesse formato. Nessa visão de relação humana e animais, esses últimos são integrantes de nossa evolução, podendo ser pela observação dos seus comportamentos e caça, pela utilização de suas partes como ferramentas e adornos ou por meio de criação de rituais e imagens míticas (PROFICE, 2016). Esse apego e interação das crianças e jovens com os animais vivos pode aprimorar a sua abordagem social e afetiva. Nesse sentido, Lee (2012) reforçou que essas interações no contexto humano da criança parecem dar suporte à sua propensão em se filiar à natureza.

\subsection{Categoria B - Elementos humanos e construídos}

Como critérios de construção dessa categoria central, foram analisados desenhos que representaram elementos construídos e/ou modificados por seres humanos (Figura 03).

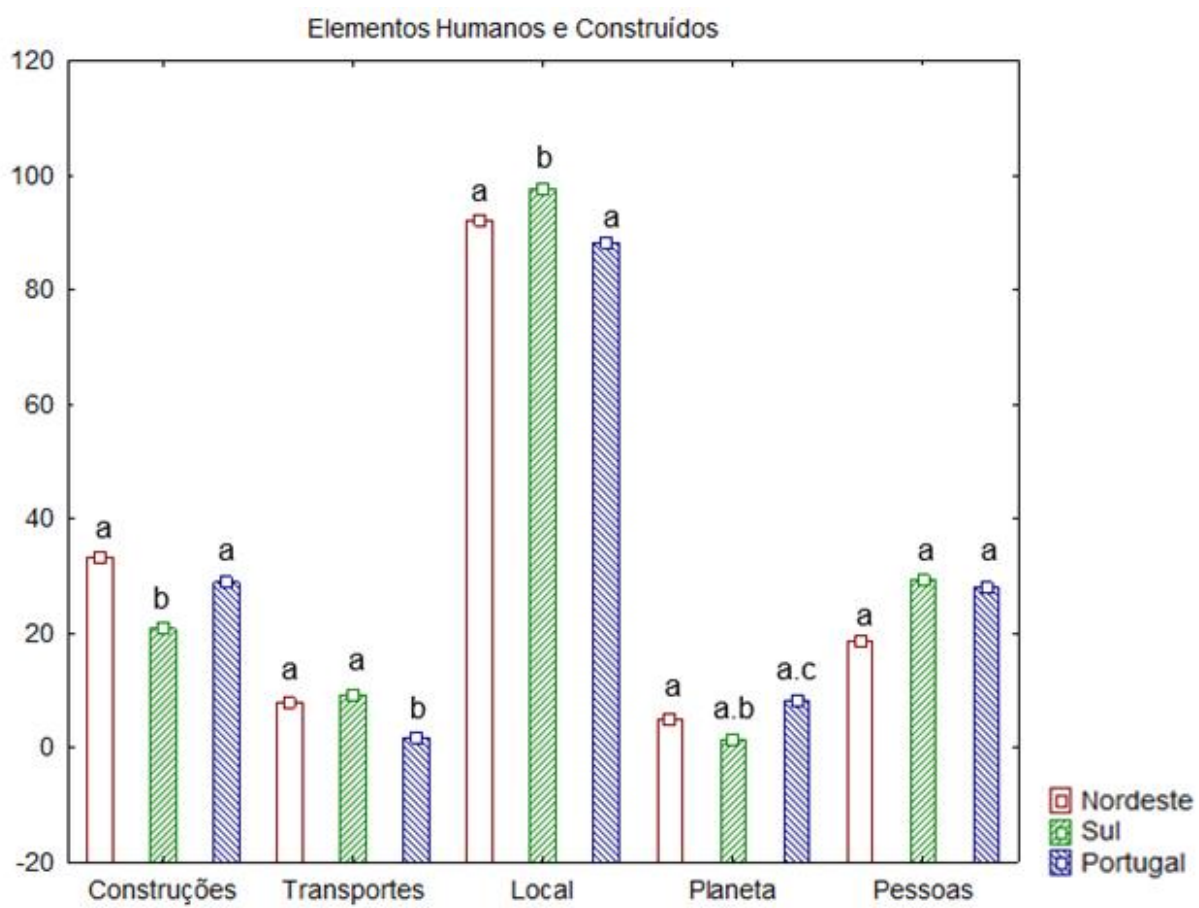

Figura 03 - A categoria central: Elementos Humanos e Construídos e as unidades de registros destacando as os valores de significâncias $(<0.05)$ para cada região estudada, Brasil (Nordeste e Sul) e Portugal ${ }^{9}$

\footnotetext{
${ }^{9}$ Legenda: as letras iguais correspondem a valores não significativos estatisticamente. Para as letras diferentes esses valores foram significativos nas regiões estudadas $(\mathrm{p}<0,05)$.
} 
Para a representação dessa categoria central, foram selecionados alguns desenhos (Figura 04) de modo a expor os elementos gráficos encontrados, bem como suas diferenças para cada região estudada.

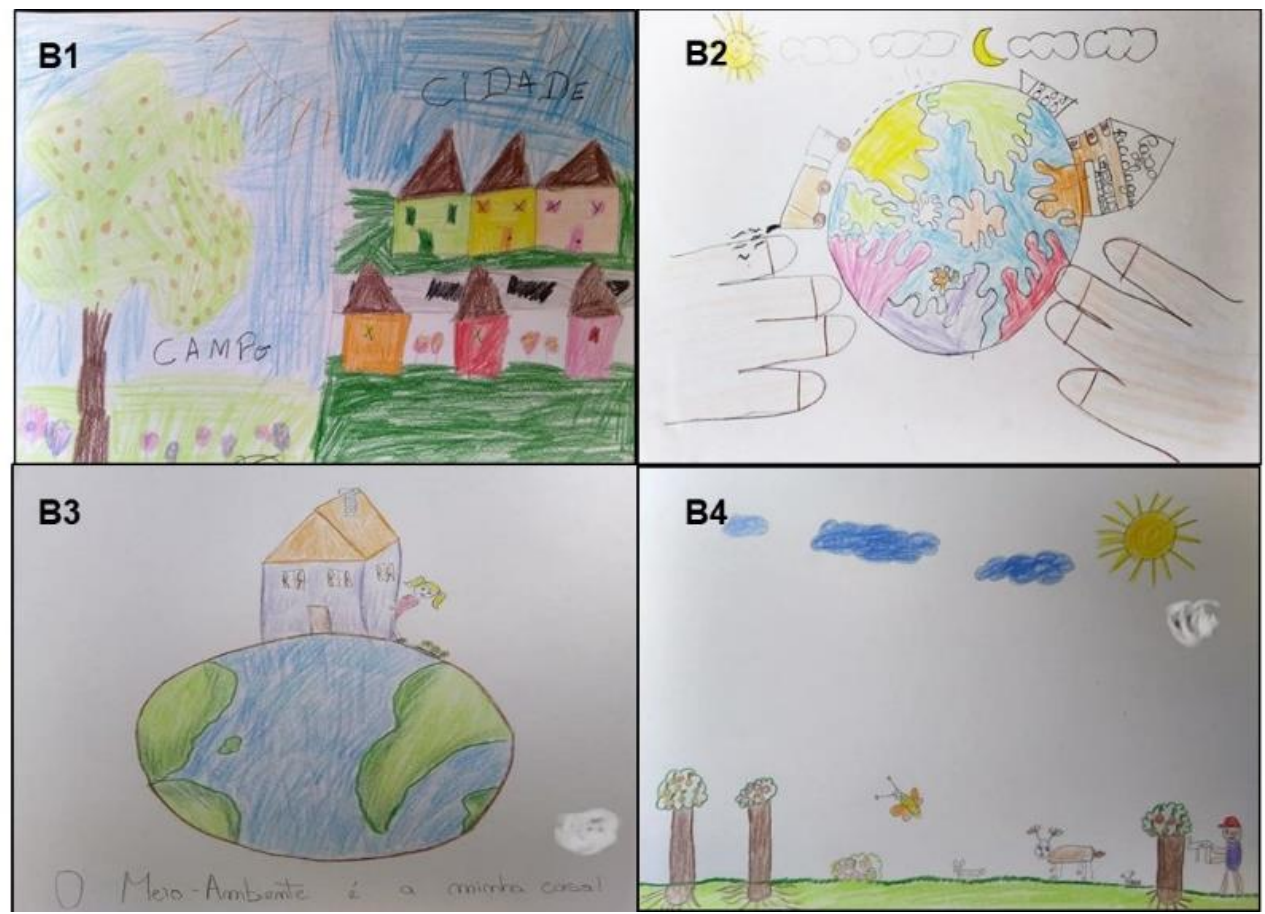

Figura 04 - Representação dos elementos gráficos dos estudantes das escolas de João Pessoa organizados em desenhos B1 e B2, estudantes de União da Vitória B3 e estudantes das escolas de Portugal caracterizado pelo desenho B4

Fonte: os autores (2019)

Como primeira análise, constatou-se que o elemento Construído, não apresentou diferenças significativas, porém, observa-se nos desenhos maior presença nas cidades de JP, seguida de UV, se comparado com a região de PT.

No cenário brasileiro em que essas regiões estão, deve-se levar em consideração o tamanho geográfico dos espaços analisados, pois se os estudantes de JP representaram com expressividade os elementos construídos, como casas, lojas, prédios e ruas, deve-se ao fato de ser uma capital de estado, com grande espaço territorial construído. Já as cidades de UV e PU, possuem um território urbanizado e população menor. Por fim, Porto apresenta inúmeras construções históricas com representatividade local, além de ser um importante centro comercial e turístico regional. Essas características são diferenciadas pelos estudantes de Gondomar, mesmo que essa cidade integre a região metropolitana da anterior, apresentando um perfil semelhante a UV e PU, tendo seus locais e espaços construídos mais dispersos.

Ao responderem à questão - O que é o meio ambiente para si? - alguns estudantes das escolas periféricas de UV e JP representaram seu meio ambiente como uma grande casa na árvore, nesse sentido, verifica-se uma grande afetividade e conectividade do ser com a natureza. Nessa percepção de afetividade e pertencimento pelo meio, Louv (2016) buscou disseminar a conexão com a natureza, em que pequenas ações como brincadeiras com galhos, folhas, terra, sementes, subir e viver em árvores, podem promover um pensamento de proteção e conservação do meio ambiente. $O$ autor reforça a necessidade de sempre reconectar-se à natureza. Essa reconexão é um processo contínuo, no qual os pais e 
educadores devem sempre fortalecer essa união com o meio. É importante essa aproximação das crianças com a natureza, visto que essa conexão com os elementos naturais promove o apego e desperta ações benéficas para a sua saúde e a do meio ambiente.

Nota-se que alguns estudantes diferem os espaços das cidades do campo (Figura 04 B1). Essa característica ficou mais evidente nos desenhos dos estudantes residentes nas áreas mais urbanizadas de JP. Nessa concepção de espaços construídos, vários desenhos mostraram ruas, praças, as casas dos estudantes e os locais turísticos. Os locais turísticos ganharam maior relevância nos desenhos de JP em relação às construções do centro histórico; PT também faz referência aos prédios históricos, além da arquitetura e urbanismo das praças, com muitas árvores, a organização e pelos seus tamanhos; por fim, UV tem como destaque a estátua no Morro do Cristo (ver Figura 02 no desenho A3).

De acordo com o que foi representado nas cidades, observa-se que o funcionamento das mesmas se dá pela mobilidade dos transportes e o fluxo das pessoas. Decorrente desse funcionamento, os estudantes ressaltam os problemas ambientais, com destaques na poluição pelos meios de locomoção, além da grande quantidade de resíduos sólidos depositados em vias públicas e de acesso humano.

Outra unidade de registro evocada foi Transporte. Com a análise estatística realizada, quantitativamente não há diferenças significativas, no entanto, verifica-se representatividade para as cidades de JP e PT, por meio de carros, ônibus, barcos, aviões e caminhões.

É evidente essa interação do ser humano com o transporte, pois serve como auxílio e facilitador nas atividades humanas, como mostram os caminhões transportadores retratados. Ao mesmo tempo que trazem esse auxílio, para os estudantes esses meios geram poluição, devido à alta eliminação de fumaça e o número destes em circulação nas rodovias.

No entanto, em desenhos dos estudantes de UV e PU, estes representaram o meio de transporte caminhão de coleta seletiva. Pode-se destacar a sensibilização ambiental, pois esses estudantes percebem a importância da coleta seletiva para que os resíduos sejam destinados para os locais corretos (Figura 04 B2).

Outro fator a ser destacado em desenhos de PT são questões da importância dos transportes para a vida humana. Os estudantes mostram a necessidade de adequações, substituições e o desenvolvimento tecnológico, para transportes mais sustentáveis. Nesse sentido, foi constatada a representação gráfica de automóveis elétricos, demonstrando uma maior sensibilização ambiental nesse quesito, se comparado com as demais regiões estudadas. Pode-se dizer que os estudantes de PT possuem visões mais futuristas, e com apelo maior ao desenvolvimento sustentável, em questões de transportes humanos ou de trabalho.

Outra unidade de registro que emergiu nas análises foi Local. Buscou-se entender uma visão local/regional do meio ambiente. Não se verificou diferença significativa, porém foi evidenciado em todas as regiões pesquisadas por meio de caraterísticas culturais e macroelementos florísticos locais.

Essa representatividade ficou marcada em estudantes das áreas mais periféricas, com o simbolismo local. Em JP foram observados aspectos de vegetação com características regionais, como cactos, cajueiros, pés de manga e coqueiros. A questão regionalismo é bastante presente na vivência desses estudantes, pelo fato de estarem próximos e conectados à natureza, possibilitando melhor acesso a essas condições. Nesse sentido, os estudantes residentes em centros mais urbanizados tendem a não ter muitos espaços para o cultivo e contato com esses elementos naturais.

Para reforçar essa expressividade e importância dessas caraterísticas locais, uma estudante destaca em seu depoimento: $O$ meio ambiente pra mim é ter cuidado com a natureza, não só com ela mais com todo o mundo que vive aqui (estudante de JP). Quando a estudante faz referência vive aqui, pode-se interpretar como a topofilia, pois ela percebe seu local. No mesmo desenho a estudante cita exemplos de atitudes ambientais cujas pessoas 
daqui (seu local) precisam realizar em prol ao meio ambiente: jogar lixo no lixo, ir de bicicleta para a escola e não jogar lixo no rio, é o que eu entendo para cuidar do meio ambiente, e finalizou seu texto com uma figura em formato de coração. Quando a criança e jovem interagem e vivenciam o mundo natural, expressam todos os sentimentos simultaneamente, por essas razões essas interações são cruciais para o seu pleno desenvolvimento, saúde e bem-estar (LOUV, 2016).

Outro destaque para as questões locais refere-se à cultura e crenças, como foi representado por um estudante de JP que é residente em um quilombo, o qual percebeu e representou o seu meio ambiente desenhando suas moradias típicas, destacando as atividades das pessoas, a coleta de frutos e a interação com animais. Com a expressividade gráfica de seu desenho, constata-se o pertencimento que este tem pelo lugar onde está, o qual faz parte de sua vida e a relação mútua, benéfica e evidente que tem com a natureza.

Um dos problemas urbanos que é debatido e carece de respostas imediatas são as construções inadequadas. Esse problema é evidenciado pelos estudantes das escolas centrais de JP. Em diversos desenhos houve a representação de comércios locais e a interação humana nesses espaços, enfatizando a degradação do meio ambiente local por meio da deposição de lixos em vias públicas.

Outra unidade de registro que emergiu durante as análises foi Planeta. Para essa, não se verificou diferença significativa estatisticamente, porém com maior representatividade de elementos nos desenhos para os alunos das regiões do PT, UV e PU.

Observou-se que poucos estudantes veem e reconhecem o meio ambiente global. Os que trouxeram essa representação, o dividem e evidenciam para a problemática ambiental. Como características para esse fato, destaca-se o desenho de uma estudante que retratou o meio ambiente como um globo terrestre dividido em duas partes, com as descrições Mau e Bom. Para a primeira, trouxe graficamente diversos resíduos sólidos depositados no mar e áreas terrestres e, ainda, carros poluindo através da fuligem dos escapamentos. É notória a expressividade de tristeza nesse ambiente, ao passo que se veem dois grandes olhos tristes, com poucas cores e simbolismo de vida. Para a segunda parte, descrita como Bom, a representação trazia diversas árvores, peixes nadando no mar e campos floridos, além de retratar um grande sorriso.

Ao verificar os desenhos dos estudantes de UV e PU, estes expressaram grandes semelhanças com os desenhos de JP. Em um dos desenhos houve a representação de dois planetas Terra. Um deles com a legenda Terra boa, com várias árvores e uma grande extensão de recursos hídricos. Já no outro lado do desenho, a Terra ruim, com árvores cortadas, queimadas e o espaço bastante seco, sem água. Nesse mesmo desenho os animais, portavam placas pedindo socorro.

Numa questão de visão global do meio ambiente, uma estudante do PT esboçou sua casa inserida sob a figura do globo terrestre (Figura 04 B3), fazendo alusão ao seu pertencimento ao ambiente, o que se confirma pela mensagem deixada pela mesma: $O$ meio ambiente é minha casa.

A última unidade de registro que emergiu para essa categoria central foi Pessoas, para a qual não houve diferenças significativas entre as cidades e países.

Observa-se que os estudantes, em seus desenhos e em elementos gráficos, não representam a figura humana como parte integrante ou pertencente ao meio ambiente percebido por eles, no entanto, os atos que são realizados no meio, sejam benéficos ou destrutivos, demonstram o ser humano no espaço. Foram poucos desenhos que contaram com a figura humana. Essa constatação também foi observada nos estudos de Martinho e Talamoni (2007) e em Reigada e Tozoni-Reis (2004), os quais verificaram nos desenhos analisados que a presença humana não foi muito reiterada. Segundo Reigota (2012), a baixa representação dos humanos pode sugerir uma definição equivocada e percepção inadequada do que 
realmente faz parte do meio em que estamos inseridos, revelando, assim, uma percepção naturalista de meio ambiente.

Para os estudantes de JP essa interação humana com o meio ambiente dá-se através de brincadeiras como soltar pipa, pular corda, jogar bola. Essa mesma interação acontece com os estudantes de UV e PU, o que difere é a relação do contato com animais e o cuidado com a natureza próxima a eles. Esse modo de brincar promove a integração dos indivíduos, em especial das crianças, em seu ambiente natural que lhe fornece espaços e elementos vivos para o aprendizado (PROFICE, 2016).

A figura humana foi expressa por uma estudante de JP, a qual representou a figura da mãe natureza, composta de macroelementos naturais como: flores, galhos e cipós ao seu redor. Essa mesma imagem faz alusão à própria estudante, o que nos leva a interpretar que há um simbolismo e afetividade, além de grande conectividade com a natureza, pois a imagem expressava alegria e afetividade.

Outro desenho representativo analisado faz referência a uma estudante de PT, ao colocar-se no desenho lendo seu livro embaixo de uma árvore. Essa imagem demonstra o apego e aproximação com a natureza que é vista numa relação biofílica à medida que se estabelece uma relação mútua entre o ser humano e a natureza e, consequentemente, essa relação permite inúmeros benefícios comportamentais, emocionais e afetivos (LOUV, 2016).

Outro desenho de um estudante de PT traz o meio ambiente como um lugar livre, onde as pessoas estão em relação mútua com as árvores e animais; retratou, ainda, as brincadeiras ao ar livre como o futebol. É importante esse contato e interação entre as pessoas e o meio natural, pois, promovem o desenvolvimento da criança, além de sua sensibilização e percepção ambiental.

$\mathrm{Na}$ questão de representatividade dos povos, o desenho da estudante de UV retratou uma tribo indígena com suas moradias tradicionais e a interação com a natureza, como no exemplo de uma jovem índia banhando-se em um riacho próximo de uma grande cachoeira. Vale ressaltar que, próximo à região não há moradias indígenas, conforme foi representado. Nesse sentido, é possível notar uma representatividade, simbolismo, afetividade e o reconhecimento da importância que essa cultura possui para o meio ambiente.

Constata-se, por meio dos desenhos, a preocupação que os estudantes possuem em relação ao meio ambiente, principalmente com a poluição antrópica. Porém, evidenciou-se num desenho de um estudante de PT a figura humana realizando a prática da caça (Figura 04 B4), a qual remete ao desrespeito e desconexão entre o humano e o animal. No entanto, essas questões de caçadas podem ser analisadas conforme três vieses.

No primeiro viés, assoma a questão de subsistência, em que populações precisam caçar para alimentar sua prole e, consequentemente, sua sobrevivência, mas possuem respeito e consciência no manejo e retirada dos recursos do meio, extraindo somente o que é necessário, a exemplo de algumas tribos indígenas que usufruem dos elementos da natureza seguindo um manejo sustentável. O segundo viés desvela uma questão cultural, em que são realizados rituais e ensinamentos de sobrevivência, nesse caso pode-se citar os índios nativos. Por último, trata-se do caçador que retira do meio os animais sem haver um manejo e desrespeitando as normas e legislações.

\subsection{Categoria C - Elementos de sentimentos ambientais}

Nessa categoria foram evidenciados os elementos humanos (pessoas) e/ou ações e sentimentos dos seres humanos com o meio ambiente (Figura 05). 


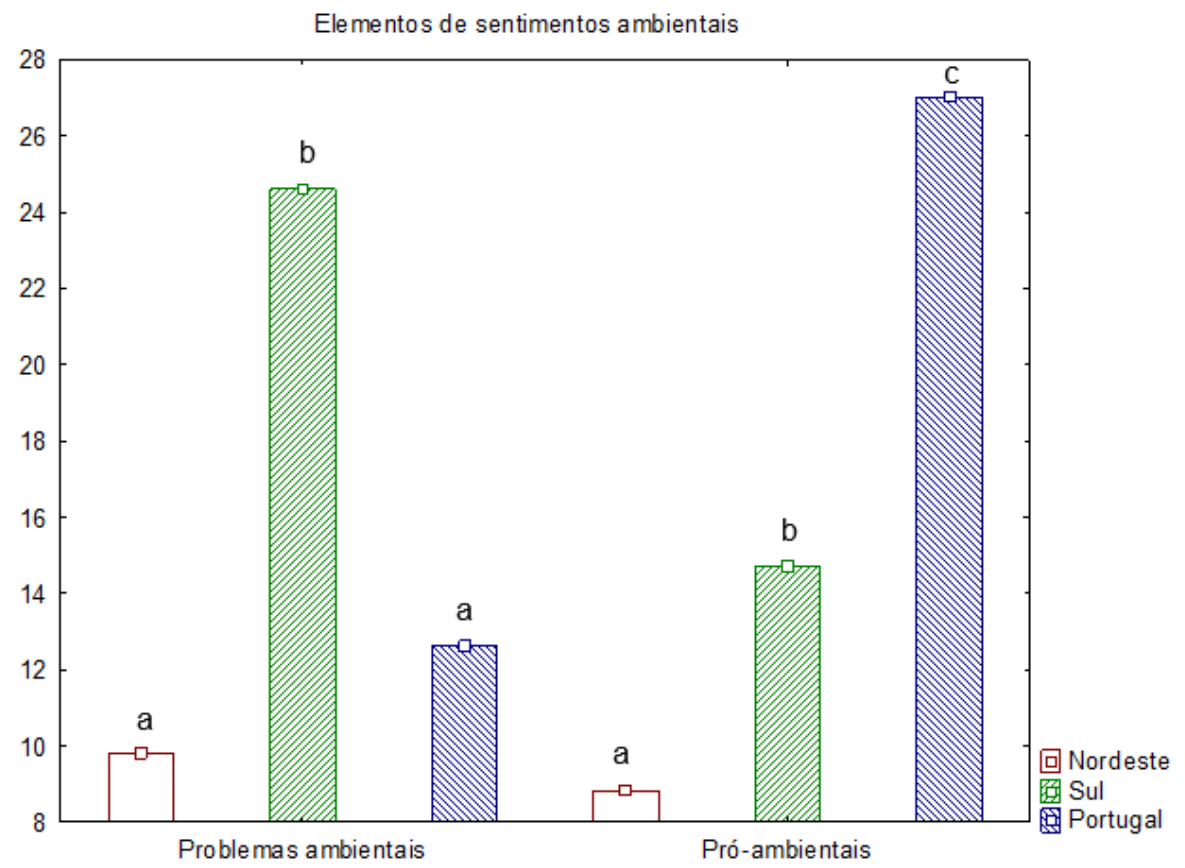

Figura 05 - A categoria central: Elementos de Sentimentos Ambientais e as unidades de registros destacando as os valores de significâncias $(<0.05)$ para cada região estudada, Brasil (Nordeste e Sul) e Portugal ${ }^{10}$ Fonte: os autores (2019)

Para representar essa categoria central, foram selecionados alguns desenhos (Figura 06), de modo a expor os elementos gráficos analisados, destacando suas diferenças entre as regiões estudadas.

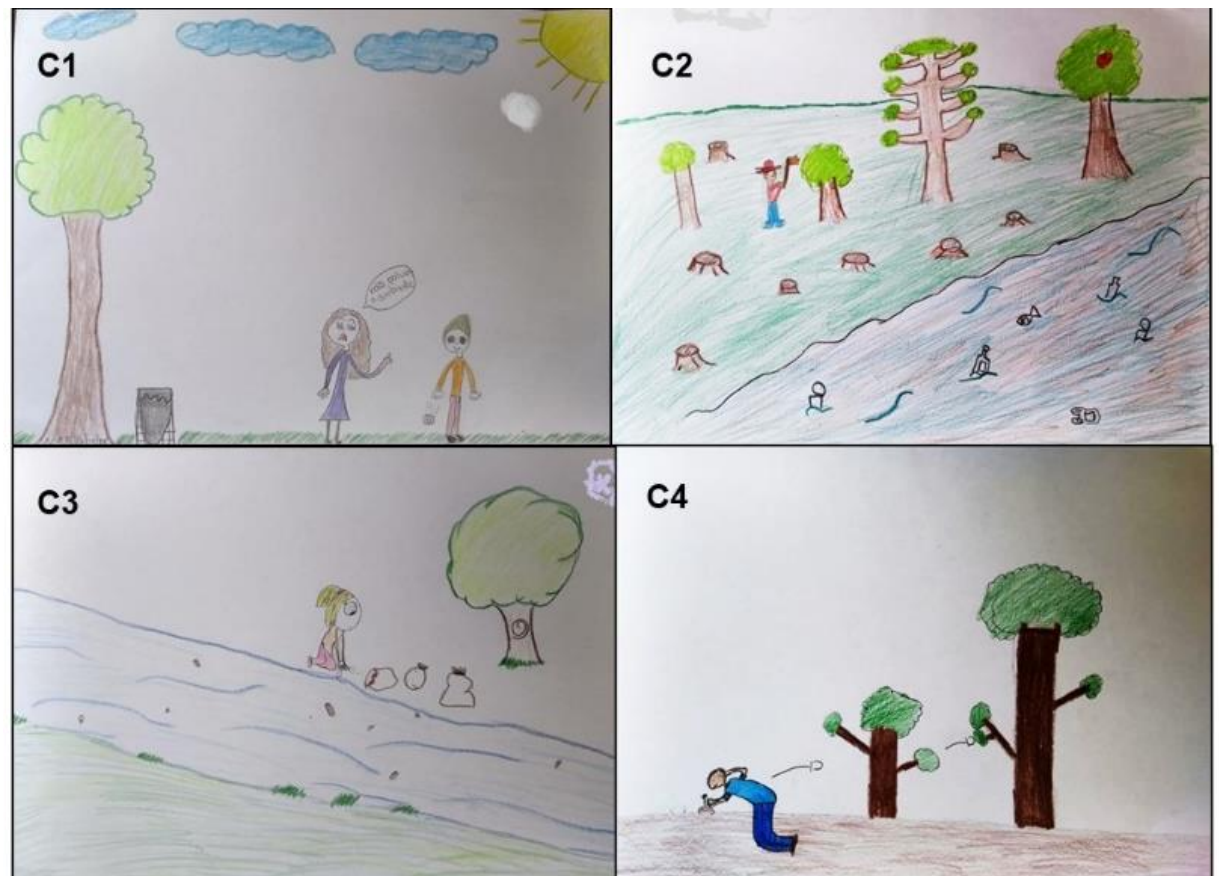

Figura 06 - Representação dos elementos gráficos dos estudantes das escolas de Portugal organizados em desenhos C1 e C2, estudantes de União da Vitória C3 e estudantes das escolas de Porto União caracterizado pelo desenho C4

Fonte: os autores (2019)

\footnotetext{
${ }^{10}$ Legenda: as letras iguais correspondem a valores não significativos estatisticamente. Para as letras diferentes esses valores foram significativos nas regiões estudadas $(\mathrm{p}<0,05)$.
} 
Para a unidade de registro Problemas ambientais não se obteve diferença significativa, no entanto, houve maior expressividade nos desenhos das escolas situadas em JP, UV e PU.

Nos desenhos apresentados pelos estudantes desses municípios, verificou-se que os problemas contra o meio ambiente são de níveis antrópicos. Conforme fora citado anteriormente, a grande questão do problema ambiental é decorrente dos resíduos depositados no chão e nos recursos hídricos. O desenho de uma estudante de PT retratou um menino jogando lixos no chão (Figura $06 \mathrm{C} 1$ ), fato esse também encontrado em outros desenhos. Nesse sentido, por intermédio de ações da EA, há grande possibilidade de reverter esse quadro problemático. Os espaços educacionais e afetivos, tais como as escolas, as famílias e as grandes instâncias de socialização, são contextos reflexivos que possibilitam a construção dos valores ambientais (BALDIN; ALBUQUERQUE, 2012). Além disso, é necessária a implementação e fortalecimento de políticas educacionais efetivas no campo formal de ensino.

Outros fatores relevantes quanto aos problemas ambientais são as queimadas, poluição do ar pelos transportes e o corte de árvores de modo ilegal e insustentável. Para essa última questão, vê-se na Figura 06 C2 a prática do corte de árvores realizada pelo humano que está com um machado em suas mãos. É importante destacar que o estudante de UV, que realizou esse desenho, reproduziu uma prática muito comum na região em que reside, em especial a remoção da mata ciliar, como foi o caso representado. Outro fator bastante preocupante e bem explícito na região foi a contaminação do rio com lixo, nesse caso o Rio Iguaçu.

Para os estudantes, situações como essas possibilitam inúmeros problemas para o meio ambiente, não somente em questões biológicas e ecológicas, mas, também, relativas à poluição visual que esses fatores trazem, e podem impactar diretamente no convívio social, cultural e biopsicossocial da população, acarretando, inclusive, grandes problemas para a saúde pública. As preocupações ambientais, ou seja, o afeto associado às crenças acerca de problemas ambientais deve encontrar um contexto facilitador de soluções para que se transforme em ações pró-ambientais (PROFICE, 2016). As crianças e jovens, na medida em que reconhecem esses problemas no ambiente, em conjunto com ações de EA, despertam as atitudes ambientais. A mesma autora descreve as atitudes ambientais como "conjunto de crenças, afeto e intenções de comportamentos que uma pessoa adota em relação a determinadas questões e atividades ambientais" (PROFICE, 2016 p.176).

Constatou-se em alguns desenhos comparações de imagens, divididas entre Boas - não poluídas, e Ruins - poluídas, conforme consta em representações de estudantes de PU, que apresentam imagens com ambiente preservado, aves voando, várias árvores verdes sobre montanhas, flores, rio limpo. Em paralelo a esse mesmo ambiente, tudo destruído com as árvores queimadas, um ambiente sem beleza natural. Nessa região ainda é comum a prática de queimadas para a agricultura, mesmo atualmente, ainda notam-se diversos locais que realizam queimadas, as quais favorecem essa problemática retratada. Fato semelhante ocorre em PT no que se refere a incêndios em grandes áreas, conforme desenhos de alguns estudantes.

Outra percepção em relação aos problemas ambientais é representada por uma estudante de PU, residente em um bairro industrial, com grandes fábricas madeireiras e produção de papel e celulose, que trouxe seu convívio local, retratando os meios poluentes dessas empresas como a fumaça das chaminés e a poluição do rio pelos rejeitos dessa produção industrial.

$\mathrm{Na}$ atualidade, com a imersão das crianças e jovens no mundo digital e globalizado, as mídias digitais e a internet exercem importante influência no reconhecimento dos problemas ambientais (PROFICE, 2016). Porém, esse fato faz com que as crianças e jovens estejam mais ambientalmente sensibilizados e conscientes, ainda que tal conhecimento não seja suficiente para que os indivíduos se sintam mobilizados para os comportamentos a favor do ambiente e, 
nesse sentido, ressalta-se a importância da EA informal e formal (LARSON; GREEN; CASTLEBERRY, 2011).

A outra unidade de registro que emergiu dessa categoria central foi Pró-ambiental; houve diferença significativa nas três regiões pesquisadas. Porém, os estudantes de Portugal demostraram em seus desenhos uma diversidade e apelo maiores para questões de melhorias e proteção relacionadas com o meio ambiente, ou seja, os estudantes de Portugal possuem visões e atitudes mais concretas quanto a ações em prol ao meio ambiente, visto que, essas são configuradas nas escolas em projetos de Educação Ambiental.

O conceito Pró-ambiental faz referência a ações comportamentais humanas positivas, favoráveis ao meio ambiente. São as motivações intrínseca e extrínseca dos indivíduos com o meio, buscando a resolução e mitigação dos problemas, que nele encontra.

De acordo com Ribeiro, Carvalho e Oliveira (2004, p. 12), o estudo do comportamento pró-ambiental pode ser definido como "um conjunto de comportamentos considerados responsáveis para a conservação, cuidado e preservação dos recursos naturais e para a manutenção da vida humana". Porém, os comportamentos são complexos porque cada um deles está sujeito à influência de fatores diversos, internos e externos os fatores ambientais, e que estão inter-relacionados principalmente com o lugar de morada de cada um.

Com isso, verifica-se que os estudantes de Portugal apresentaram mais desenhos próambientais/ativos com relação à conservação, devido ao fato que há maior ênfase nas ações e concretização das mesmas por meio de políticas e gestões públicas. Enquanto que em JP ou SC e PR deve haver mais a vivência dos problemas ambientais, sem muitas ações concretas ou somente medidas paliativas com relação à recuperação ambiental, sendo que em JP constata-se urgência nesse aspecto de falta de ações de recuperação. Em JP, através dos elementos gráficos dos estudantes verifica-se menor percepção dos problemas, porque há menos sensibilidade em relação ao meio ambiente, logo não veem graves impactos como problemas. Muitos problemas como esgoto a céu aberto, por exemplo, passam a ser condições consideradas normais e não são reconhecidas como problemas.

Nos desenhos analisados observou-se um grande apelo para o cuidado, preservação e proteção do meio ambiente. É notória essa preocupação que os estudantes mostram, os quais se veem como protagonistas para fazer a diferença. Cabe ressaltar que, no estudo de Arbogast et al. (2009), os autores referenciam a infância como um período chave para o desenvolvimento da consciência e das atitudes positivas em relação à natureza. Em outro estudo, realizado por Erdogan e Marcinkowski (2012), os autores defendem a importância de envolver as crianças, desde cedo, em atividades ao ar livre e em ambientes naturais. É a partir do conhecimento que as experiências de natureza, diretas ou indiretas, na infância, podem estar relacionadas com o comportamento pró-ambiental na sua vida adulta, ou seja, serão adultos mais sensibilizados e conscientes quanto às atitudes ambientais (PROFICE, 2016).

A estudante da escola de PT demonstra essa preocupação com a fauna e flora, ao passo que regava e cuidava de flores e ajudava os animais. Essas atitudes demonstram o apego à natureza, decorrente das relações de amor que a pessoa vivencia em sua infância. Porém, ao mesmo tempo em que há a preocupação com a proteção da natureza, necessita-se dela para a subsistência humana, para o lazer e alimentação, o que, para muitas pessoas, pode implicar numa sensação de independência e superioridade diante da natureza (JORDAN, 2009). Mas, para que haja um equilíbrio, é necessário adquirir hábitos, atitudes sustentáveis e uma visão globalizante da natureza (REIGOTA, 2012). É necessário promover o desenvolvimento de um self ecológico de apego seguro, o amor pela natureza e preocupação com o planeta estão intrinsecamente relacionados com as relações amorosas iniciais (JORDAN, 2009).

O que ficou evidenciado nos desenhos das crianças de todas as regiões, são os resíduos sólidos, pois trouxeram os recipientes com separações de acordo com a classificação de cada resíduo (metal, papel, vidro e orgânico), isso dá alusão a que os estudantes têm conhecimento 
sobre a coleta seletiva, além da presença de caminhões com as pessoas que realizam a coleta dos resíduos. Essas práticas, na maioria das vezes, são aprendidas nos espaços formais de ensino, é nas escolas que os estudantes vivenciam projetos relacionados com EA, como o exemplo (Figura 06 C3), em que muitas escolas realizam a remoção dos resíduos sólidos. Com essas práticas os estudantes podem replicar seus conhecimentos, impactando positivamente a sociedade. Ainda reforçando a importância da imersão dos estudantes no mundo ambiental, essa imersão deve ser estimulada, pois a sensibilização ambiental começa no berço, ou seja, o primeiro passo deve ser dado na infância. Deve-se ensinar a criança a observar a beleza e os segredos da natureza. A criança não entenderá as razões do funcionamento da natureza, mas aprenderá a observar, o que constitui a primeira etapa na formação de uma sensibilização e consciência ecológica e o amor à natureza (COLACIOS, 2011).

Essa noção de separação dos resíduos por meio da coleta seletiva, muitas vezes, tem seu início no ensino formal. Nos espaços escolares, tais temas são debatidos e apresentados aos estudantes, enfatizando-se a importância dessas atitudes relacionadas com a destinação correta dos resíduos. As instituições de ensino brasileiras, em seu nível básico, devem apresentar em seu Plano Político Pedagógico projetos, ações e atividades de EA, de maneira interdisciplinar, e cabe aos docentes e à equipe pedagógica efetivarem essas propostas, adequando-as aos níveis e modalidades de ensino. A importância da EA é comprovada em vários estudos, um desses, realizado por Pauw, Donche e Van Petegem (2011), corrobora que a EA sendo efetiva e contínua, de fato, possui capacidade de interferir nas atitudes ambientais das pessoas, de modo a promover novos tipos de comportamentos mais pró-ambientais.

Os estudantes de todas as escolas e regiões acreditam que uma das maneiras para tentar solucionar essa problemática ambiental é por meio da difusão de informações. Em alguns desenhos, observaram-se placas indicando e instruindo quanto aos problemas de jogar lixo no chão, conforme a seguinte mensagem: $O$ meio ambiente é bonito, mas tem muita gente só sabe poluir ele, lixo na lixeira (estudante de UV).

Outras mensagens expressas foram sobre a natureza: Natureza pra mim é, não poluir o ar e o meio ambiente. Nunca poluir a natureza não cortar as árvores. Nunca poluir o meio ambiente! (estudante de UV); Viva na natureza, Ajude a cuidar da Terra porque você vive nela (estudante do PT). Por meio dessas mensagens, os estudantes mostram seus valores ambientais, pois enaltecem o mundo natural ou a questão ambiental, através de suas crenças e atitudes.

Para compreender cientificamente essas relações humanas perante o meio ambiente, busca-se na Psicologia Ambiental, a qual apresenta dois perfis de pessoas. O primeiro perfil abrange as pessoas que se consideram diferentes, não pertencentes e, portanto, superiores à natureza (PROFICE, 2016). Nesse mesmo raciocínio, apresenta-se um dos conceitos sobre o meio ambiente, o antropocentrismo, o qual tem a visão de que o meio ambiente deve favorecer somente ao ser humano, não havendo uma reciprocidade sustentável com a natureza (REIGOTA, 2012). Já no segundo perfil se enquadram as pessoas que se consideram parte da natureza, e com os mesmos direitos de todos os demais seres vivos. Vale destacar que esse segundo perfil foi percebido na maioria dos estudantes (PROFICE, 2016).

Outras atitudes pró-ambientais trazidas pelas crianças relacionam-se à limpeza das praias. Verifica-se nas crianças essa preocupação, conforme mensagem: Meu planeta limpo e os animais seguros (estudante de PT). Nota-se a preocupação que a estudante tem em relação ao meio ambiente, principalmente no aspecto da poluição, a qual se sente parte do ambiente no momento em que escreve meu planeta, ainda faz a associação à poluição com a insegurança ou problemas com animais.

Outras expressões gráficas remetem ao plantio de árvores, indicando que os estudantes acreditam que se fosse realizado efetivamente melhoraria essa problemática. Observa-se o 
estudante de UV realizando o plantio de árvores (Figura 06 - C4), com isso há a efetiva prática ambiental e compreensão por parte do estudante do desenvolvimento sustentável, em que aquela planta servirá para as gerações futuras.

Nesse caso, a arborização, o plantio de árvores torna-se extremamente importante, pois a presença de árvores, arbustos e flores no ambiente em todos os locais, em especial o urbano, tende a melhorar o clima, traz sombreamento e embelezamento das cidades, além de diminuição da poluição atmosférica pela absorção de gases, sonora e visual e, ainda, contribuem para a melhoria física e mental dos seres humanos. O embelezamento dessas áreas verdes promovem o bem-estar, biofilia (WILSON, 1984) e a conexão humana biopsicossocial (PROFICE, 2016) com a natureza/ambiente (LOUV, 2016).

Cabe ressaltar que o plantio de árvores em locais públicos como praças, entorno de ruas, parques entre outros, possibilita a redução significativa da sobrecarga dos sistemas de drenagem de águas pluviais, melhorando, quanto possível, a infiltração no solo e auxiliando na redução da velocidade de água das tempestades e, também, evitam outros problemas, como as enchentes e erosões (TROWBRIDGE; BASSUK, 2004).

$\mathrm{Na}$ questão de plantio de árvores, a floresta nativa deve ter prioridade no plantio, se comparado com as espécies exóticas. A primeira é destacável, pois estas são mais adequadas por preservarem outros recursos naturais, particularmente a biodiversidade, abrigam espécies de animais de maior porte, que exigem espaços maiores e são interligados por corredores florestais (ZULAUF, 2000).

Um estudante de PU expressa um ambiente de fazenda com árvores frutíferas, pés de milho e flores. Ele se coloca no desenho juntamente com seu pai, semeando a terra. A importância que a família tem na formação da criança, em diversos aspectos, mas se tratando de questões ambientais, os ensinamentos dos pais são passados aos filhos. Reforçando a importância familiar na vida da criança e jovem, um estudo realizado por Cheng e Monroe (2012), com estudantes do Ensino Fundamental da Florida/EUA, reconhece que os valores familiares são bons preditores da conexão com a natureza e do interesse em práticas próambientais, como experiências prévias na natureza aumentam a sua conexão com o meio, assim como o sentimento do fazer, para a melhoria ambiental.

O desenvolvimento de ações voltadas para a preservação e conservação do ambiente possibilita a mudança de atitudes diante das problemáticas socioambientais. Nesse sentido, Chawla (2009) alude que a motivação na criança e jovem para cuidar da natureza influencia na tendência a ser ambientalistas na vida adulta. Essa influência ocorre na medida em que os indivíduos estão imersos na cultura adulta, além da convivência do seu grupo social.

\section{Considerações Finais}

Após as análises dos desenhos, constata-se que os estudantes das diferentes cidades e países identificam inúmeras problemáticas ambientais, seja em nível local ou global e, consequentemente, mostram grande preocupação com os recursos naturais que estão se exaurindo devido às ações antrópicas.

Verifica-se, nas expressões gráficas, que uma das problemáticas ambientais identificadas pelos estudantes de ambos os países são os resíduos sólidos depositados pelos seres humanos de maneira inadequada, principalmente em corpos hídricos e no solo, os quais afetam diretamente os ciclos biológicos da natureza, consequentemente impactando negativamente a biodiversidade.

Cumpre destacar que os estudantes identificam e reconhecem os problemas ambientais, mostram preocupação com o meio ambiente. Nesse quesito, os estudantes portugueses representaram em seus desenhos em quantidades maiores de atitudes ambientais positivas, o que nos leva a inferir que esse público possui atitudes pró-ambientais mais 
consistentes se comparado com os estudantes brasileiros. Justifica-se esse fato, pois nos desenhos portugueses visualizam-se elementos gráficos com medidas efetivas e sustentáveis para questões ambientais, os quais são diminutos nos desenhos dos estudantes brasileiros.

Por se tratar de uma pesquisa no campo educacional, tem-se na EA possibilidades de novas alternativas para a formação e desenvolvimento de uma postura crítica diante das questões que englobam o contexto em que se vive. Para tanto, a compreensão dos pensamentos e opiniões dos estudantes torna-se necessária para suprir essa demanda. Neste estudo esses parâmetros foram observados por relatos e, principalmente, por meio da expressão artística, uma vez que essas percepções individuais e as representações socioambientais possibilitaram vislumbrar um perfil socioambiental dos estudantes. Com isso, pode-se direcionar ações mais efetivas para as questões ambientais locais, regionais e globais, além de melhorar as políticas públicas que visem a relação humana com o meio ambiente e a necessidade da EA contínua nos espaços formais e informais, buscando a mudança de paradigmas humanos.

\section{Referências}

ARBOGAST, K. L., KANE, B. C. P., KIRWAN, J. L., HERTEL, B. R. Vegetation and outdoor recess time at elementary schools: What are the connections? Journal of Environmental Psychology, Liverpool, v. 29, n. 4, p. 450-456, 2009. Disponível em:

<https://www.sciencedirect.com/science/article/abs/pii/S0272494409000255>. Acesso em: 5 jun. 2019.

BALDIN, N.; ALBUQUERQUE, C. Cidadania ecológica. Concepções e práticas de estudantes universitários. Saúde e Multiculturalidade. Fórum Sociológico, Lisboa, v. 22, n. 2, p. 1-15, 2012. Disponível em: <https://journals.openedition.org/sociologico/681〉. Acesso em: 20 jun. 2019.

BARDIN, L. Análise de conteúdo. Lisboa: Edições 70, 2009.

BEZERRA, T. M. O.; GONÇALVES, A. A. C. Concepções de meio ambiente e educação ambiental por professores da Escola Agrotécnica Federal de Vitória de Santo Antão-PE. Biotemas, Florianópolis, v. 20, n. 3, p. 115-125, 2007. Disponível em:

<https://periodicos.ufsc.br/index.php/biotemas/article/view/20679>. Acesso em: 5 ago. 2019.

CHAWLA, L. Growing Up Green: Becoming an Agent of Care for the Natural World. Journal of Developmental Processes, s/l, v. 4, n. 1, p. 6-23, 2009. Disponível em: http://citeseerx.ist.psu.edu/viewdoc/download?doi=10.1.1.519.8387\&rep=rep1\&type=pdf. Acesso em: 10 ago. 2019.

CHENG, J. C-H.; MONROE, M. C. Connection to Nature: Childrren's Affective Attitude Toward Nature. Environment and Behavior, s/1, v. 44, n. 1, p. 31-49, 2012. Disponível em:

<https://journals.sagepub.com/doi/abs/10.1177/0013916510385082>. Acesso em: 8 mai. 2019.

COLACIOS, R. D. Energias alternativas e a educação ambiental: uma proposta de transformação social e de cidadania. In: ALMEIDA, J. P de; COLACIOS, R. D. (Orgs.). Ambiente e sociedade trajetos de história, ecologia, política e educação ambiental. Porto Alegre: Escritos, 2011. p. 42-62.

ERDOGAN, M., OK, A.; MARCINKOWSKI, T. J. Development and validation of children's responsible environmental behavior scale. Environmental Education Research, s/l, v. 4, n. 18, p. 507540, 2012. Disponível em:

<https://www.researchgate.net/publication/241715312_Development_and_validation_of_Children's_R esponsible_Environmental_Behavior_Scale>. Acesso em: 25 mai. 2019. 
FRIDRICH, G. A.; BALDIN, N. Percepções Socioambientais de crianças sobre o Rio Iguaçu nos Municípios de União Da Vitória (PR) e Porto União (SC). Revista Educação e Cultura Contemporânea, Rio de Janeiro, v. 14, n. 36, p. 1-24, 2017. Disponível em: http://periodicos.estacio.br/index.php/reeduc/article/viewArticle/1211. Acesso em: 30 ago. 2019.

JODELET, D. Conferência de Denise Jodelet por ocasião do recebimento do título de Doutor Honoris causa da Universidade Federal do Rio de Janeiro. In: SOUSA, C. P. de. et al. (Org). Representações sociais estudos metodológicos em educação. São Paulo: Fundação Carlos Chagas/Champagnat, 2011. p. 19-39.

JORDAN, M. Nature and self - na ambivalente attachement? Ecopsychology, s/l, v. 1, n. 1, p. 26-31, 2009. Disponível em: <https://www.researchgate.net/publication/251773260_Nature_and_Self An_Ambivalent_Attachment>. Acesso em: 20 mai. 2019.

KAHN, P. H. Developmental psychology and the biophilia hypothesis: Children's affiliation with nature. Developmental Review, s/l, v. 17, p. 1-61, 1997. Disponível em:

<https://www.sciencedirect.com/science/article/pii/S027322979690430X>. Acesso em: 8 mai. 2019.

LARSON, L. R.; GREEN, G. T.; CASTLEBERRY. Construction and Validation of an Instrument to Measure Environmmental Orientations in a Diverse Group of Children. Environment and Behavior, s/l, v. 43, n. 1, p. 72-89, 2011. Disponível em:

<https://www.researchgate.net/publication/249624614_Construction_and_Validation_of_an_Instrume nt_to_Measure_Environmental_Orientations_in_a_Diverse_Group_of_Children>. Acesso em: 16 abr. 2019.

LEE, P. C. The Human Child's Nature Orientation. Child Developement Perspectives, s/1, v. 6, n. 2, p. 193-198, 2012. Disponível em:

<https://www.researchgate.net/publication/263382856_The_Human_Child's_Nature_Orientation>. Acesso em: 20 abr. 2019.

LOUV, R. A última criança na natureza: resgatando nossas crianças do transtorno do déficit da natureza. Tradução Alyne Azuma, Cláudia Belhassof. São Paulo: Aquariana, 2016.

MARTINHO, L. R.; TALAMONI, J. L. B. Representações sobre meio ambiente de alunos da quarta série do ensino fundamental. Ciência \& Educação, Bauru, v. 13, n. 1, p. 1-13, 2007. Disponível em: <http://www.scielo.br/scielo.php?pid=S1516-73132007000100001\&script=sci_abstract\&tlng=pt $>$. Acesso em: 20 abr. 2019.

MORIN, E. Os sete saberes necessários à educação do futuro. Tradução de Catarina Eleonora F. da Silva e Jeanne Sawaya. 2. ed. São Paulo: Cortez/ Brasília: UNESCO, 2000.

PAUW, J. B.; DONCHE, V.; PETEGEM, P. V. Adolescents' environmental worldview and personality: An explorative study. Journal of Environmental Psychology, Liverpool, v. 31, n. 2, p. 109-117, 2011. Disponível em:

<https://www.sciencedirect.com/science/article/abs/pii/S027249441000054X>. Acesso em: 20 jan. 2019.

PEDRINI, A.; COSTA, É. A.; GHILARD, N. Percepção Ambiental de crianças e pré-adolescentes em vulnerabilidade social para projetos de Educação Ambiental. Ciência \& Educação, Bauru, v. 16, n. 1, p. 163-179, 2010. Disponível em:

<http://www.scielo.br/scielo.php?pid=S151673132010000100010\&script=sci_abstract\&tlng=pt $>$.

Acesso em: 16 abr. 2019. 
PROFICE, C. As crianças e a natureza: reconectar é preciso. São Paulo: Pandorga, 2016.

REIGADA, C.; TOZONI-REIS, M. F. C. Educação Ambiental para crianças no ambiente urbano: uma proposta de Pesquisa-Ação. Ciência \& Educação, Bauru, v. 10, n. 2, p. 149-159, 2004. Disponível em: $<$ http://www.scielo.br/scielo.php?pid=S1516-73132004000200001\&script=sci_abstract\&tlng=pt $>$. Acesso em: 5 abr. 2019.

REIGOTA, M. O que é educação ambiental? 2. ed. São Paulo: Brasiliense, 2012.

RIBEIRO, M. J. F. X; CARVALHO, A. B. G. C.; OLIVEIRA, A. C. B. O estudo do comportamento pró-ambiental em uma perspectiva behaviorista. Revista Ciências Humanas, v. 10, p. 177-182. Disponível em: http://pepsic.bvsalud.org/scielo.php?script=sci_nlinks\&ref=465411\&pid=S1415711X201800010000400019\&lng=pt. Acesso em: 18 ago. 2020.

SCHULTZ, P. W. Connecting with nature. Scientific American, 2009. Disponível em: https://www.scientificamerican.com/article/moral-call-of-the-wild/. Acesso em: 18 ago. 2020.

SCHULTZ, P.W., KAISER, F. G. Promoting Pro-Environmental Behavior. In: CLAYTON, S. (Ed.), The Oxford Handbook of Environmental and Conservation Psychology. New York: Oxford University Press, 2012. p. 661-691.

SCHWARZ, M. L.; SEVEGNANI, L.; ANDRÉ, P. Representações da mata atlântica e de sua biodiversidade por meio dos desenhos infantis. Ciência \& Educação, Bauru, v. 13, n. 3, p. 369-388, 2007. Disponível em: <http://www.scielo.br/scielo.php?script=sci_abstract\&pid=S1516$73132007000300007 \& \operatorname{lng}=e n \& n r m=i s o \& t \operatorname{lng}=p t>$. Acesso em: 5 mai. 2019.

STEFFEN, W. Sustainability. Planetary boundaries: guiding human development on a changing planet. Science, Rockville, v. 347, n. 13, p. 01-12, 2015. Disponível em: https://www.ncbi.nlm.nih.gov/pubmed/25592418. Acesso em: 12 jul. 2019.

TELLES C. A.; SILVA, G. L. F. Relação criança e meio ambiente: Avaliação da percepção ambiental através da análise do desenho infantil. Rev. TechnoEng: Centro de Ensino Superior dos Campos Gerais - Cescage, 2012.

TROWBRIDGE, P. J. ;BASSUK, N. L. Trees in the Urban Landscape: Site Assessment, Design, and Installation. Wiley, 2004, p. 232.

TUAN, Y. Topofilia: um estudo da percepção, atitudes e valores do meio ambiente. São Paulo: Difel, 1990.

WILSON, E. O. Biophilia. Cambridge: Harvard University Press, 1984.

ZULAUF, W. E. O meio ambiente e o futuro. Estudos Avançados, São Paulo, v.14, n.39, p. 85-100, 2000. Disponível em: <http://www.scielo.br/pdf/ea/v14n39/v14a39a09.pdf>. Acesso em: 17 ago. 2020. 